\title{
Between Mimesis and Alterity: Art, Gift, and Diplomacy in Colonial India, 1770-1800
}

\author{
NATASHA EATON \\ School of Art history \& Archaeology, The University of Manchester
}

What I mean by mimesis . . . [is] a 'space between,' a space permeated by the colonial tension of mimesis and alterity, in which it is far from easy to say, who is the imitator and who is the imitated, which is copy and which is original.

Michael Taussig (1993:p.78)

Today cultural thingness is on the agenda. What Appadurai has called "methodological fetishism" has become the byword for a new type of inquiry into the ontology of possession and circulation of things. ${ }^{1}$ Of these, the Maussian 'gift' has emerged as an organizing topos for other institutions of exchange not structured by the contractual rationality of commodity. ${ }^{2}$

Unfortunately, there is a persistent tendency in the recent literature on gift to conflate it with one-sided generosity: the 'true' gift is anti-economic, gratuitous - "expenditure."3 For Derrida, in order for there to be a gift "there must be no reciprocity, return, exchange, counter gift or debt. If the other gives me back or owes me or has to give me back what I give him or her, there will not have been a gift"; the gift "is annulled each time there is restitution or counter gift." ${ }^{4}$ It needs to be emphasized that real gift institutions are based on intricate calculation which, though very different from utilitarian calculus, are never-

Acknowledgments: Research for this paper was funded by the British Academy, The Leverhulme Trust, Yale University, the Simon Fund, and the Nehru Trust. I am indebted to the following scholars for their insights and patience in reading various drafts: P. J. Marshall, C. A. Bayly, Linda Colley, Christopher Pinney, Tapati Guha-Thakurta, Michael Rosenthal, Brian Allen, Mark Crinson, Naby Avcioglu, Kate Retford, Urmila De, and Bhaskar Mukhopadhyay. I am especially grateful to Thomas Trautmann and the anonymous readers at $\mathrm{CSSH}$ for their advice and suggestions for revision. The responsibility for the remaining infelicities is mine.

1 Arjun Appadurai, "Introduction: Commodities and the Politics of Value," in, A. Appadurai ed., The Social Life of Things: Commodities in Cultural Perspective, Cambridge: Cambridge University Press, 1986, 3-63; and John Frow, "Gift and Commodity," in Time and Commodity Culture: Essays in Cultural Theory and Postmodernity, Oxford: Clarendon Press, 1997.

2 Marcel Mauss, The Gift: The Form and Reason for Exchange in Archaic Societies, W. D. Halls, trans., London: Routledge, 1990.

3 Jacques Derrida, Given Time: I. Counterfeit Money, Peggy Kamuf, trans., Chicago: University of Chicago Press, 1992.

4 Ibid., p. 11.

0010-4175/04/816-844 \$9.50 C 2004 Society for Comparative Study of Society and History 
theless wholly irreconcilable with what Bataille calls dépense (absolute giving, loss, expenditure). ${ }^{5}$ If the real cannot be mined to generate cases to fit the Bataillian dépense or the Derridean gift-as-excess, the conclusion is that these involutions are generated by the very economy of (post-Romantic) thought which these thinkers claim to have superseded.

If gift is no longer what it used to be (amongst avant-garde French philosophers), the category of commodity is also undergoing radical rethinking. When commodity, following Appadurai, is defined in terms of a situation, a state from which things can flow in and out in the course of their 'social' lives, the categorical bipolarity of gift versus commodity becomes difficult to hold on to. This is more so when most gifts are gifts of commodities - as in today's world. It follows that gift and commodity exchanges are not mutually exclusive: there are conventions everywhere about what can properly be bought and sold and what cannot, and the line demarcating the two is determined not by the categorical bipolarity of 'expenditure' versus 'economy' but by the specific culturalinstitutional strategies of singularization. ${ }^{6}$

It seems to me, the distinction between alienable and inalienable possessions, proposed by Annette Weiner, is the most effective way of grappling with these variable cultural strategies of singularization. In her thesis, highly prized things are valued more if they are suspended from circulation, as they are imbued with the charisma of the giver that is hard to return, difficult to give away, even hazardous to receive. ${ }^{7}$ Inalienable possessions like the Maori taonga or titles or heirlooms in the West acquire their force and scarcity-value (singularization) in two ways: first, from the fact that they are heritable within a closed descent group, having an exclusive and cumulative identity with a particular series of owners; and second, from their ties to cosmological forces-the dead, ancestors, gods, or sacred places. The crucial fact about such possessions is that they cannot, under most circumstances, be freely exchanged: their authority makes them a key source of social and political prestige and hence of social hierarchy. This is why these are objects of intense competition.

My concern in this essay is to explore the intercultural negotiations around 'gift' in early colonial India. Most ethnographies of gift would have us believe that its locale is the non-occidental world, blatantly disregarding that the West has its own gift institutions, whose negotiations with their non-Western counterparts have rarely been studied. ${ }^{8}$ In contrast, I attempt to show that in early

5 Georges Bataille, "The Notion of Expenditure," in Visions of Excess: Selected Writings, 19271939, Allan Stoekl et. al, trans., Minneapolis: University of Minnesota Press, 1985, p. 118.

6 See Scott Cutler Shershow, "Of Sinking: Marxism and the "General Economy," Critical Inquiry 27 (Spring) 2001:468-92.

7 Annette B.Weiner, Inalienable Possessions: The Paradox of Keeping-While-Giving, Berkeley: University of California Press, 1992.

8 An important exception that explores the creation of a historically located 'colonial' gift is Nicholas Thomas, Entangled Objects: Exchange, Material Culture and Colonialism in the Pacific, Cambridge, Mass.: Harvard, 1991. 
colonial India, 'gift' created a forum for transcultural negotiations. What sustains the narrative is my claim, against the grain, that gift cannot be taken as an analytical resource to be counterposed against commodity in such a way as to make their relationship a basis of comprehensive periodization, producing the stabilities of 'a now' and 'a then,' as in so many accounts of colonial modernity. ${ }^{9}$ Gift, I hope to demonstrate below, is ontologically heterogeneous, possessing different valences in different contexts.

This paper examines the interface between Mughal and British 'regimes of inalienability,' and documents how the 'image-gift' became central to AngloIndian diplomacy. I analyze the construction of colonial portraits as both gift and tribute - a practice initiated by the first Governor-General Warren Hastings (1772-1785). Ordered by the Directors of the East India Company to impose direct rule on the kingdom of Bengal, Hastings was instrumental in extending the Company's influence to the wealthy kingdoms of Mysore, Awadh, the Carnatic, and the Deccan, and he became one of the most powerful rulers in South Asia. As part of his aggressive foreign policy, Hastings dispatched British portraitists to indigenous courts where they were to paint the likenesses of Indian rulers, to be sent to the Company authorities as gift. In late eighteenth-century India, the English East India Company wanted to replace the quintessential Mughal gift of khil'at (rulers' robes) and nazr (tribute money) with their own form of gift-symbolically potent portraits. This portrait-gift presupposed a certain relationship between the donor and the recipient underpinned by a mimetic ideology of presence unrelated with the Mughal idea of tribute-gift. Both were highly personalized — 'inalienable' — transactions that aimed to transmit the 'presence' of the donor to the recipient. Yet 'presence' signified very differently for these two regimes, and one of the aims in this essay is to signpost their crossings and negotiations.

My focus here is on the colonial hybridization of the metropolitan practice of gifting portraits and its imbrication with other diacritics. It is in this connection that I draw on Taussig's idea of mimesis and colonialism as a privileged site for mimetic encounter. ${ }^{10}$ He revives the very ancient idea of the mimetic aptitude as an anthropological constant, suggesting that the ability to mime, and mime well, is the capacity to Other. Taussig injects into this concept an extraordinary analytical depth: far from being an inferior mode of cognition typical of 'savage thought' (as in Frazer's "sympathetic magic"), he makes it the basis of knowledge about the Other. He establishes the idea of "sentient knowing" through mimetic acts by which the copy acquires power over the original.

\footnotetext{
${ }^{9}$ For example, in the context of eighteenth-century India, Sen has argued that British colonialism displaced the regime of gift with that of commodity and the market. See Sudipta Sen, An Empire of Free Trade: The East India Company and the Making of the Colonial Marketplace, Philadelphia: University of Pennsylvania Press, 1998.

${ }_{10}$ Michael Taussig, Mimesis and Alterity: A Particular History of the Senses, New York: Routledge, 1993.
} 
Through a subtle reading of colonial copies of metropolitan originals, he arrives at the notion of 'mimetic excess' - mimesis turned on itself leading to mimetic self-awareness - which I propose to use here. Just as Hastings wanted to emulate Mughal emperors as part of the Company's legitimization exercise, so indigenous rulers wanted to 'copy' the British by incorporating British art into their collections. In exploring this politics of circulation of mimesis in alterity, I want to bring out the centrality of 'art' in the colonial encounter-its ability to format novel kinds of agencies, institutions and subjectivities. In this sense alterity is best understood not through the narrative disjuncture between two pre-existing essences, implying the "linear equivalence of event and idea," but through the entanglement of unequal times - of contingent, shifting and unstable orderings. ${ }^{11}$ Alterity is enacted and performed rather than scripted beforehand in seamless discursive closures.

\section{LIKENESS AS PRESENCE: GOVERNING GIFT IN COLONIAL INDIA}

'Gift' was fundamental to the formation and maintenance of the multi-layered Mughal polity: subordinates offered valuable tributes-nazr, and received in return khil'at-robes minutely graded in terms of rank and occasion from the wardrobe of the ruler, signifying a certain incorporation into the king's body as well as the body politic. ${ }^{12}$ Kingly charisma consisted in giving 'excessively' kings styled themselves as the 'embodiment of hospitality.' ${ }^{13}$ Drawing on ideas of sovereignty from Turkish, Persian, Hindu and other local practices, the nawabs of the Mughal 'successor states' negotiated with multiple sacred and profane symbols.

However, in the late 1760s the Company's Court of Directors started to view the entanglement of its employees in Mughal gift rituals with anxiety and suspicion, and they dismissed these practices as bribery and extortion innate to 'Oriental despotism.' ${ }^{14}$ At the heart of the matter lay the Company officials' abuse of the Mughal gift. It became a regular practice to accept bribes and make threats against the persons and property of indigenous rulers and traders unless they 'gave' generously. Responding to these escalating charges of corruption, the Regulating Act of 1773 prohibited British officials from receiving land, money, and jewels from Indians. ${ }^{15}$ This measure had curious repercussions: the

11 Homi Bhabha, The Location of Culture, London: Routledge, 1994, p. 140.

12 F. Buckler, "The Oriental Despot," in, M. Pearson, ed., Legitimacy and Symbol, Ann Arbor: University of Michigan Press, 1992; Stewart Gordon and G. Hambly, eds., Robes of Honour: The Medieval World of Investiture, New York: St. Martin's Press, 2000.

13 Mir Muhammad Taqi 'Mir,' Zikr-i Mir: The Autobiography of the $18^{\text {th }}$-century Mughal Poet: Mir, C. M. Naim, trans., Delhi: Oxford University Press, 1999, p. 124. Here he refers to his patron Asaf ud-daula, nawab of Awadh, to be discussed below. See M. Brand, The Vision of Kings: Art and Experience in India, Canberra: Australian National University Press, 1997.

14 John McLane, Land and Local Kingship in $18^{\text {th }}$-century Bengal, Cambridge: Cambridge University Press, 1993, p. 43.

15 At the same date, the Company abolished the annual Puniyah ceremony at the prince (nawab) 
Indo-Persian chronicler Ghulam Hussain Tabataba'i deplored the fact that as a result of the Act, Calcutta's Supreme Council "constantly refuse the nazrs presented them in compliance with a custom peculiar to India and they returned untouched even presents of fruit." 16 The refusal of fruit qua gift signified the ultimate transgression of Mughal civility ( $a d a b$ ), when gifts were returned to the sender. ${ }^{17}$

Under the post-1773 'reformed' gift regime, "gifts [were] allowed . . . to have legal validity ... only if they were given for reasons deemed satisfactory in British courts of law, which proposed new taxonomies of gifts and new ideas of political expediency." 18 Hastings tried to devise a new kind of gift that reconfigured elements from Mughal and British gifting practices. Although his own accounts and the Calendar of Persian Correspondence reveal that on occasion he would still present khil ${ }^{2}$ ats and receive nazr, these instances increasingly became marginal. ${ }^{19}$ Instead, Hastings wanted to replace the erstwhile gift of land grants, jewels, and money with a symbolic and highly personal form of gift - the painted portrait. In eighteenth-century Britain, portraits played a key role in strengthening kinship networks: two-dimensional images were believed to convey a certain presence of the absent donor through the mediation of likeness. ${ }^{20}$ The dissemination of portraits extended to the diplomatic realm, and no ambassador quitted Britain without likenesses of the reigning monarch. While these canvases evoked his presence, they did not stand in for the absent sovereign (as in France), a practice that the British abhorred as 'despotic.' George III sent multiple versions of his own likeness to the Crown's colonies in America, the West Indies, and Minorca and at the suggestion of Lord Pigot, (former Governor of the Company's settlement in Madras), he even 'gifted' his likeness to the nawab of Arcot.

By the 1750s, Arcot had come under indirect Company rule, although the ruler still played off the French and the British against each another so as to assert his power. To reciprocate George III's image-gift, Nawab Muhammad Ali (under pressure from the Company) ordered his own portrait from the first British professional artist to visit India-Tilly Kettle (fl. 1768-1776) - then

of Bengal's court at Murshidabad. This had been a highly symbolic occasion when all the important land rentiers in the kingdom of Bengal offered tribute money in return for robes.

${ }^{16}$ Ghulam Hussain Tabataba'i, Siyar al-muta' akhkhirin: History of Modern Times, Haji Mustapha, trans., London: Oriental Trust Fund, 1832, vol. 2, p. 461.

17 Barbara Metcalf, ed., Moral Conduct and Authority: The Place of Adab in South Asian Islam, Berkeley: University of California Press, 1984.

18 Nicholas B. Dirks, "From Little King to Landlord," in, N. Dirks, ed., Colonialism and Culture, Ann Arbor: University of Michigan Press, CSSH Book Series, 1992, p. 200.

19 Warren Hastings, Durbar Accounts, 1780-85, Hastings Papers, British Library (hereafter BL), Add Ms. 29,092.

${ }^{20}$ Louise Lippincott, "Expanding on Portraiture: The Market, the Public and the Hierarchy of Genres in $18^{\text {th }}$-Century Britain," in, A. Bermingham and J. Brewer, eds., The Consumption of Culture: Image, Object, Text, London: Routledge, 1995. 
stationed at Madras. ${ }^{21} \mathrm{He}$ wrote to the English king: "I have Your Majesty's picture night and day before me, endeavoring to console myself by imagining that I have the honor of being ever in your Majesty's Presence. I was desirous of attending in person Your Majesty to return my grateful thanks for the favor of Your Majesty's picture ... I have sent Your Majesty the picture of myself and my children, together with some cloths and some rosewater, hoping that the picture may have that honor of being affixed in Your Majesty's royal sight."22

Surely the "presence" Muhammad Ali is describing is very different from the presence immanent in Western portraits. The initial success of this image-gift must have prompted Hastings to incorporate the protocol of gifting of portraits in his diplomatic repertoire. Due to his lack of contacts in London's royal circles, George III could not be called upon to gift his portrait to every nawab. So Hastings substituted his own portrait for that of the king.

Mughal Emperors occasionally disseminated their likenesses and collected European art, but these practices were peripheral to their practices of sovereignty. Akbar (1556-1605) distributed his own miniature portrait to select 'disciples' in votive ceremonies associated with the worship of the sun known as shast wa shabah. Neophytes declared four decrees of devotion, placing their heads at the ruler's feet in extreme prostration, before he presented them with a turban, a medallion embossed with a sunburst, pearl earrings, and a tiny portrait to be worn in the turban. ${ }^{23}$ Akbar and his successor Jahangir (1605-1627) also received Jesuit and British envoys, who used art as a diplomatic gift in their ploys for religious and trade sanctions, with varying degrees of success. In spite of the many altarpieces commissioned in Goa, Lisbon, and Rome, or engravings sourced from the Netherlands, the Jesuit fathers failed to use images to convert the Mughal court. ${ }^{24}$ Whilst the English ambassador Sir Thomas Roe (1616-1619) speculated that Jahangir seemed pleased with a miniature portrait of James I, he warned his English contacts that only the highest quality pictures would do. ${ }^{25}$ Subsequently, the East India Company attempted to introduce British art as both gift and commodity across the Mughal Empire, but its factory records expose the lack of Indian enthusiasm for European pictures and the controversies surrounding their circulation, payment, and profits. ${ }^{26}$ The situa- $^{-}$

21 For Arcot, see J. D. Gurney, The Nawab of Arcot's Debts. D. Phil thesis, Oxford University (unpublished), 1968; and H. D. Love, Vestiges of Old Madras 1640-1800: Traced from the East India Company's Records . . for the Government of India, Madras: John Murray, 1913.

22 Muhammad Ali, quoted in Court Correspondence, xviii, January 1770, cited in Love, Vestiges, p. 123 (my emphasis).

23 John F. Richards, The Mughal Empire, Cambridge: Cambridge University Press, 1996, p. 45.

24 Gavin Bailey, Counter Reformation Imagery and Allegory in Mughal Painting, Ph.D. thesis (unpublished), Harvard University, 1996, p. 134.

25 Sir Thomas Roe, The Embassy of Sir Thomas Roe to India, 1615-19, William Forster, ed., Oxford: Oxford University Press, 1926, pp. 76-77.

26 G. Forster, ed., Early Factory Records of the East India Company, London: Thacker, 1902, vol. 5 . 
tion further deteriorated when Emperor Aurangzeb (1658-1707) condemned shast wa shabah as idolatrous and ordered the defacement of the Jesuit-inspired frescoes of Christian saints in his predecessors' palaces at Lahore and Agra. ${ }^{27}$

Although Company officials occasionally received albums of images from the important public men-even from the current Emperor Shah Alam, art was not axiomatic to Mughal diplomacy. ${ }^{28}$ Consequently, the gifting of pictures between the Company and Indian princes had made little progress by the $1750 \mathrm{~s}$. Hastings (when Resident at the nawab of Bengal's court) used other artifacts (wax figurines, china, glassware, and pistols) to mediate social relations with regional rulers. ${ }^{29}$ So, on becoming Governor-General, why did he promote his own portraits-as-gift? He "believed that the British rulers of Bengal must conduct a foreign policy within a diplomatic system comparable to that of Europe," whilst simultaneously upholding at least some outward appearance of Indian diplomacy based on "face-to-face relations." 30 As part of this ambivalent gesture, Hastings supplemented English ideas of diplomacy with his interpretation of Akbar's munificent artistic practices. Akbar's chronicler Ab'l Fazl recorded, "His Majesty himself sat for his likeness and also ordered to have the likenesses taken of all of the grandees in the realm. An immense album was thus formed; those who had passed away have received new life and those who are still alive have immortality promised them." 31 Again, this practice had little to do with portrait-exchange.

Hastings ordered the translation of the sections on art from Akbar's chronicle, the Ain-i-Akbari, and he collected as many miniatures from Akbar's studio as possible and sent the English landscape painter William Hodges to portray the forts, cities, and monuments from Akbar's reign. But this is where Hastings' emulation of Akbar ended. Pictorially, according to Mughal convention, kings were usually represented in action (conversation, warfare, hunting, and other courtly rituals), in contrast with Hastings' own portraits where he is usually seated alone except for those objects (a chintz waistcoat and a Persian seal) that contribute to the construction of his 'Oriental' identity (figure 1). He sat for every British portraitist passing through Calcutta and commissioned the distribution of his portraits-as-prints amongst his political allies in Britain and India. They, in (re)turn, penned odes to these likenesses - the picture became Hast-

27 Bailey, Counter Reformation Imagery, p. 44.

28 Muzzafar Alam and Seema Alavi, A European Experience of the Mughal Orient: The I jazi Arsalami-Persian Letters, 1773-79 of Antoine Polier, Delhi: Oxford University Press, 2001, p. 34.

29 See C. R. Wilson, Early Annals of Bengal, London: Thacker, 1900, vol. 2, app. 22; and Warren Hastings, Residency Accounts at the Court of Murshidabad, Bengal, 1758, BL: Add Ms. 29,092, f. 14, which records gifts for the nawab of Bengal consisting of china, broadcloth, "several glasses and things of small value which I shall endeavor to procure for him."

30 P. J. Marshall, "The Making of an Imperial Icon: The Case of Warren Hastings," Journal of Imperial and Commonwealth History 27, 3, 1999, p. 6.

31 Ab'1 Fazl, The Aini Akbari-The Institutes of Akbar, H. Blochmann, trans., London, 18731896, vol. 1, p. 115. 


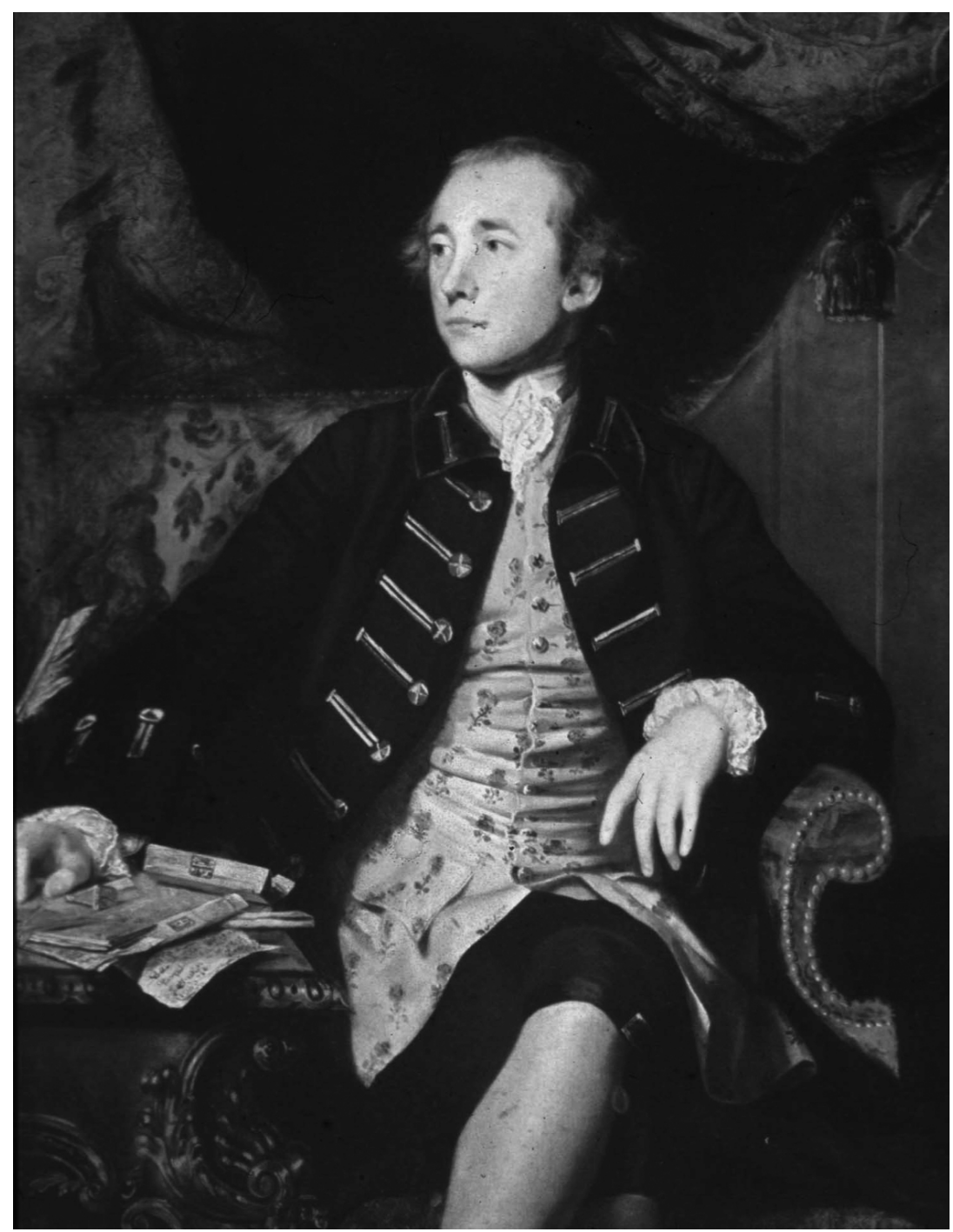

Figure 1. Sir Joshua Reynolds, Warren Hastings, 1766-1768, oil on canvas, by permission of the National Portrait Gallery, London.

ings in his absence. ${ }^{32}$ One of his acolytes in north India, the French creole Haji Mustapha, sighed: "To no purpose do I search for solace in roaming from seat to seat, garden to garden ... nothing is green for me now; these once pleasing spots

32 There are at least nineteen British and six Indian paintings of Hastings, yet no portrait of Hastings was hung in a public building during his governorship. For details of a mezzotint after 
have become so many dreary deserts . . . some people observed that I was talking to his picture, a picture of striking likeness by the inimitable Zophani [sic]."33

But how did Hastings' portraits signify in Indian courtly contexts? The IndoPersian practice of royal letter writing (insha) was grounded on the writer's desire to be in the presence of the reader. This affective investment on letter as a mediator of absence could extend to the perception/reception of Western portraits (as seen in the case of the nawab of Arcot's correspondence with George III). Yet, for the nawabs caught up in the network of Hastings' designs, British portraitsas-gifts also assumed more ominous significations that were not reportable in their correspondence with the British. By the 1780s, Indian officials at the independent court of Hyderabad believed that when the Company contrived to annex an Indian state they would send messages of friendship, accompanied by European novelties offered as gifts, before asking for a land grant so as to establish a small factory, which would then be armed ready for strategic interventions into the kingdom's affairs. ${ }^{34}$ So, as much as the artifacts themselves, the strategic timing of giving, obliging, and receiving also constituted their agency.

Richard Johnson, the Company Resident (envoy) at Hyderabad, tried to compare the giving of portraits with the exchange of 'inalienable' Indian objects. On his arrival in the summer of 1784, he failed to assert Hastings' influence at court where the dominant external force was Nana Phadnavis, Prime Minister of the Marathas - the Company's enemy. To gain favor, assisted by gifts, Johnson drew the Hyderabad ruler Nizam Ali Khan into far-reaching plans to give him a dominant position in south India, if he allied with the British. Nizam Ali Khan's authority was to be established over the Carnatic territory held by Muhammad Ali, and in return the nizam would make huge payments to the British, pay off Arcot's debts, and maintain a British brigade in the Carnatic at his own expense. ${ }^{35}$

During these negotiations, Johnson wrote to Hastings: "I presented your picture [figure 2] handsomely framed to the soubah [the nizam] as a peculiar mark of friendship requiring his in exchange, a mode which I said amongst us was familiar to your interchange of turbans. He accepted it as such and is making up a picture in return. You will see how much this pleased him by his particular mention of it in his letter as what he prized much above all the other valuable presents to be laid before him by me from you." 36

Reynolds' portrait of Hastings issued at a time of crisis in 1776, see Hastings Papers BL: Add Ms. 29,138 48,245,458; Add Ms. 29,173 306; Add Ms. 29,159 83; and J. J. Pratt, "On Seeing a Portrait of Warren Hastings," Add Ms. 29,235, f. 174.

${ }^{33}$ Haji Mustapha, introduction to his translation of Ghulam Hussain Tabataba'i, Siyar al-muta' akhkhirin, vol. 1, pp. 14-15.

${ }^{34}$ Abd al-latif Shustari, Tuhfat al- 'Alam Pers. Ms. Elliot 382, Bodleian Library Oxford 16776, cited in Gulfishan Khan, Indo-Muslim Perceptions of the West in the $18^{\text {th }}$ Century, Karachi: Oxford University Press, 1998, pp. 58-59.

35 P. J. Marshall, "Richard Johnson: Career of a Collector" (MS). I am grateful to the author for providing a copy of this paper.

36 Richard Johnson to Hastings; Hastings Papers BL: Add Ms. 29,167, f. 253, 20 Dec. 1784. 


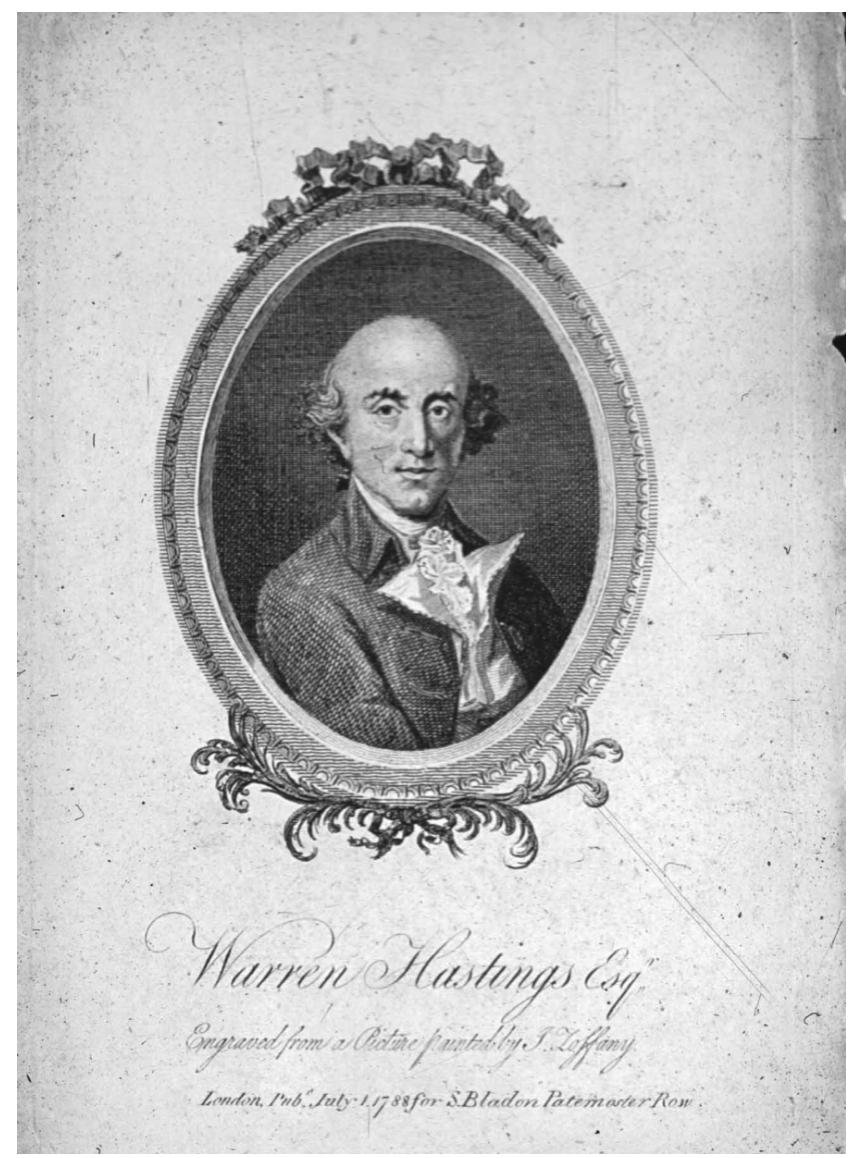

FIGURE 2. Richard Brittridge, after Johann Zoffany, Warren Hastings, 1786, line engraving, Courtesy of the Lewis Walpole Library, Yale University.

The inalienability elicited by pictorial mimesis helped to mediate transactions between Johnson, Hastings, and Nizam Ali Khan. The following spring the nizam entrusted Hastings (who was about to resign and return to London) with a diamond ring to be gifted to George III. But in the eyes of the British public, this gift (lacking the element of inalienable presence that portraits had) was not truly 'singular' and Hastings was even accused by his metropolitan opponents of trying to bribe the English king. He became the butt of graphic satire as a base, calculating official seeking royal favor through gifts Satirists (see figure 3) deliberately distorted the pose and physiognomy of two of Hastings' most famous portrait prints (figures 1 and 2), playing on the idea of likeness as an extension of the person whilst simultaneously exposing his corruption. 


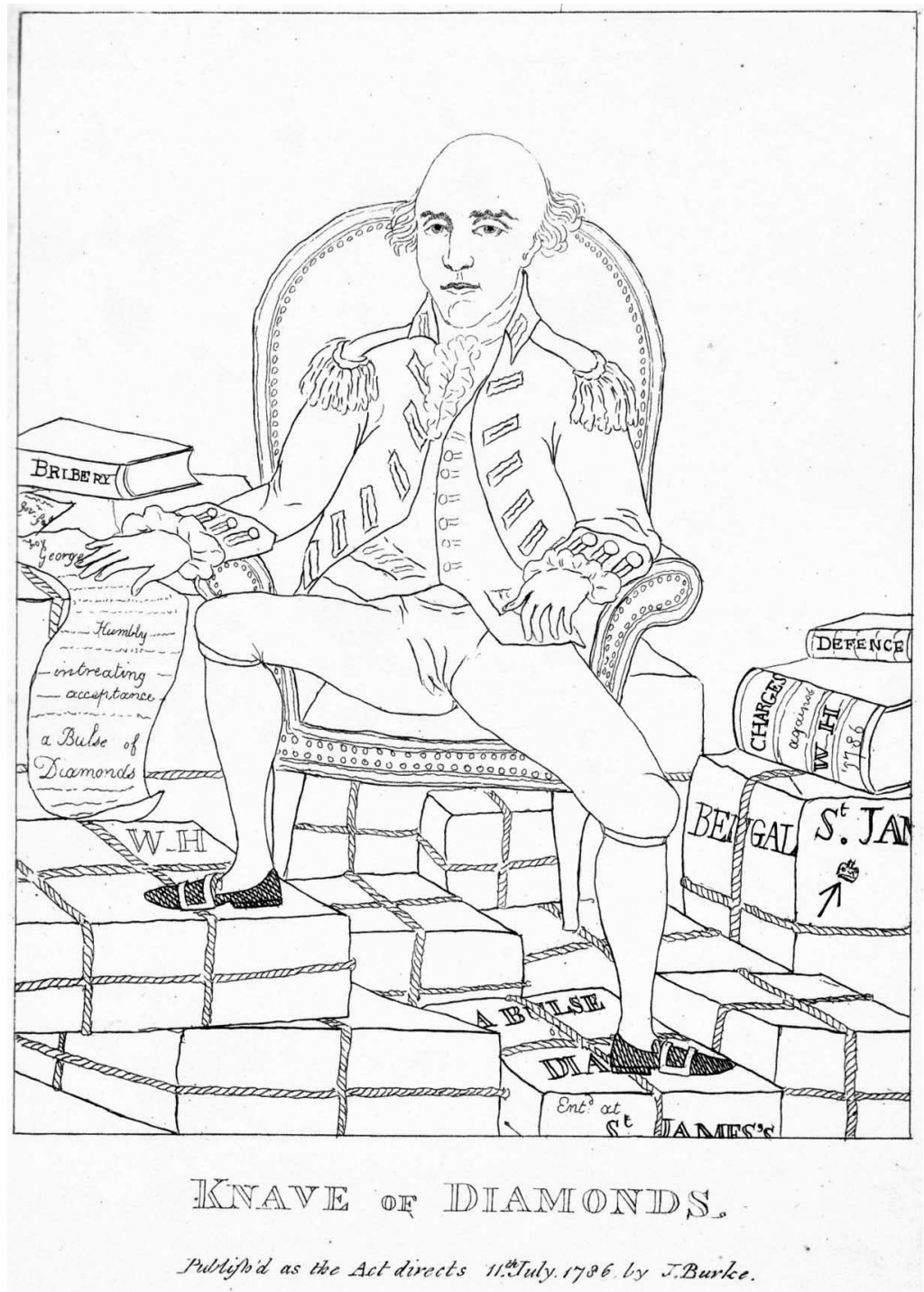

FIGURE 3. Anonymous British satirist, The Knave of Diamonds, 1786, etching, by permission the Trustees of the British Museum, London.

By this time, political relations between the Company and Nizam Ali Khan had deteriorated. No return image is recorded in Johnson's letters or in the Calendar of Persian Correspondence, perhaps due to the Resident's swift recall in February 1785, the subsequent dissolution of any alliance plans and the difficulty in tracing images from Hastings' disbursed art collection. However, a like- 
ness of the nizam in one of Johnson's albums suggests that the ruler did compose a return image, which, perhaps due to his own increasingly strained relationship with Hastings, Johnson decided to keep (figure 4). Painted by one of his court artists, Nizam Ali Khan is seated cross-legged in profile on a Persian rug with a mosque behind him projecting a very different presence to Hastings' direct gaze and life-size visage which demands immediate engagement with the viewer (figure 2). ${ }^{37}$

Johnson's album also included his own portrait, that of Hastings (after Zoffany, figure 5), and the likeness of the ruler of Awadh, all painted by provincial Mughal artists. Both Hastings and Johnson were collectors of Mughal art, competing over rare images from Delhi, Hyderabad, and especially from the north Indian city of Lucknow, the capital of the semi-independent state of Awadh. A wealthy cultural center, Lucknow had been the target of Company expansion since the 1770s where Hastings and the Supreme Council dispatched several Political Residents to implement the Company's agenda of gradual annexation. Like Arcot, Lucknow became the hotbed of European intrigue - that wealthy site where traders, soldiers, diplomats, and later artists all sought to make their fortunes. $^{38}$ The nawab Asaf ud-daula (1775-1797) threatened to write to George III if the Company did not reduce his payments and remove its Resident, forcing Hastings to spend five months at Lucknow in 1784 in an attempt to improve Anglo-Indian relations. ${ }^{39}$ Hastings invited one of George III's former favorites, Johann Zoffany, as his official artist, instructing him to take likenesses of the nawab. Although Asaf was portrayed by Tilly Kettle when he was heir apparent in 1771, he, like his father Shuja ud-daula before him, expressed no subsequent desire to patronize British artists. ${ }^{40}$

Shortly after Hastings' arrival, the heir to the Mughal throne, Jawan Bakht, fled from Delhi to take refuge at Lucknow, where he sat to Zoffany, prompting Asaf to do the same. ${ }^{41}$ But Asaf quickly disposed of his portrait by giving it to a disgraced Company official, as a gesture of contempt for the Company's policy. The Governor-General left Lucknow in August 1784, having failed to reach

37 These portraits acted as some of the illustrations to the work of the poet Mir Qamar Minnat (India Office and Oriental Collections-hereafter OIOC, Ms. Or. 6633) in Johnson's possession; Mildred Archer and Toby Falk, Indian Miniatures in the India Office Library, London: Sotheby Parke Barnet, 1981, Introduction.

38 Richard Barnett, North India Between Empires: Awadh, the Mughals and the British, 17201801, Berkeley: University of California Press, 1980.

39 Calendar of Persian Correspondence, Imperial Archives Series, 1911, vol. 5, 20 May 1781. Asaf wanted the Resident Bristow to be recalled; if Hastings did not comply, he also threatened to write to the British Prime Minister.

40 Following his work for the nawab of Arcot in the late 1760s, Kettle traveled to the city of Faizabad in Awadh where he took the likenesses of the nawab Shuja ud-daula and his sons. A French colonel noted that Shuja ordered his court artists to make miniature versions of these British canvases, which he preferred; Colonel Gentil, Memoirs sur l'Hindoustan, Paris, 1810, p. 43.

41 It seems to have been Zoffany's normal practice to take five or six sittings for a portrait, which was also continued at the court of Lucknow. See Hastings, Diary, Hastings Papers BL: Add Ms. 39,879 . 


\section{NATASHA EATON}

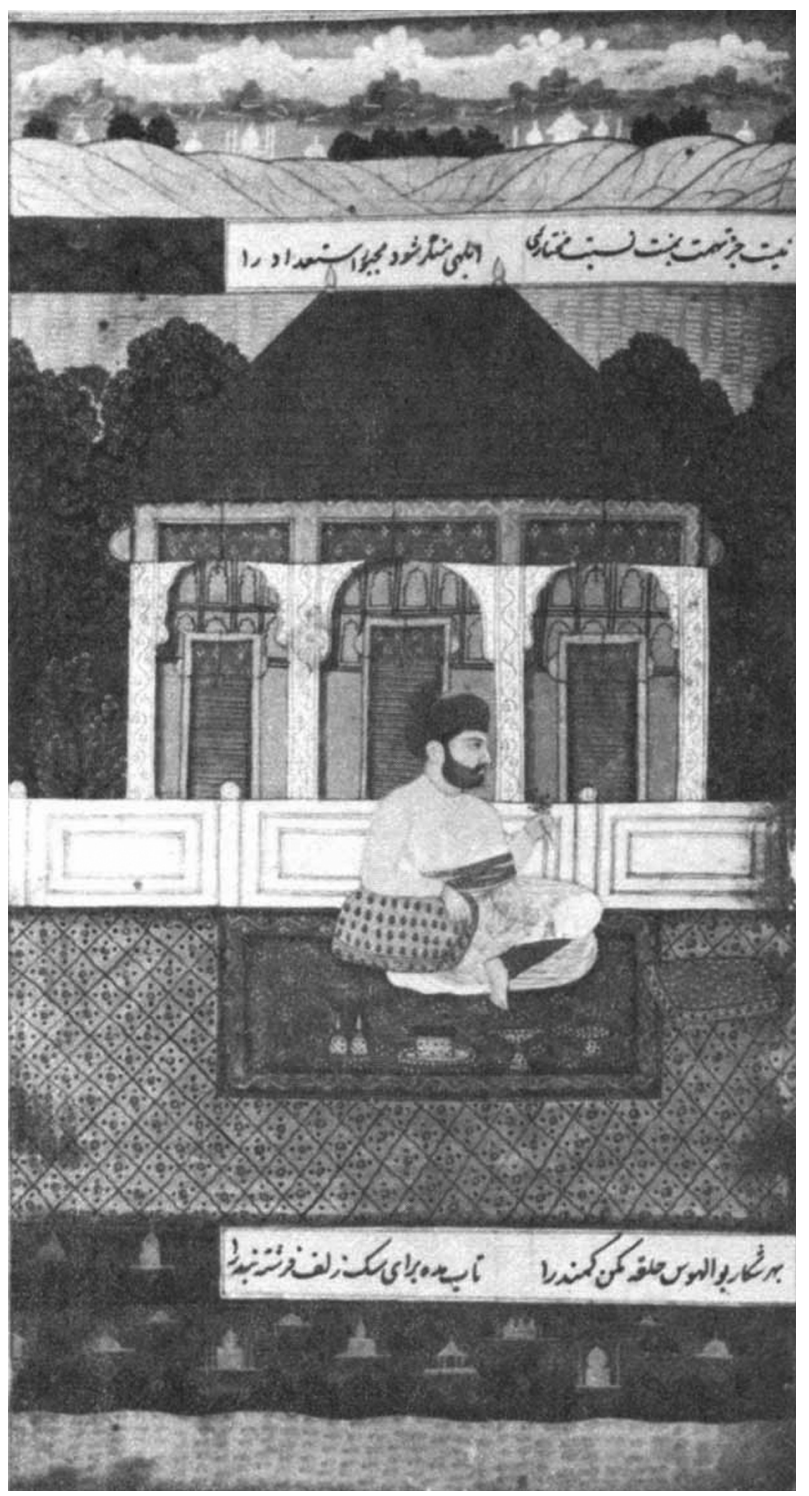

Figure 4. Anonymous Mughal artist, Nizam Ali Khan, c.1784-1785, gouache and gold leaf, Add Or. 6633, Oriental and India Office Collections, by permission of the British Library, London. 


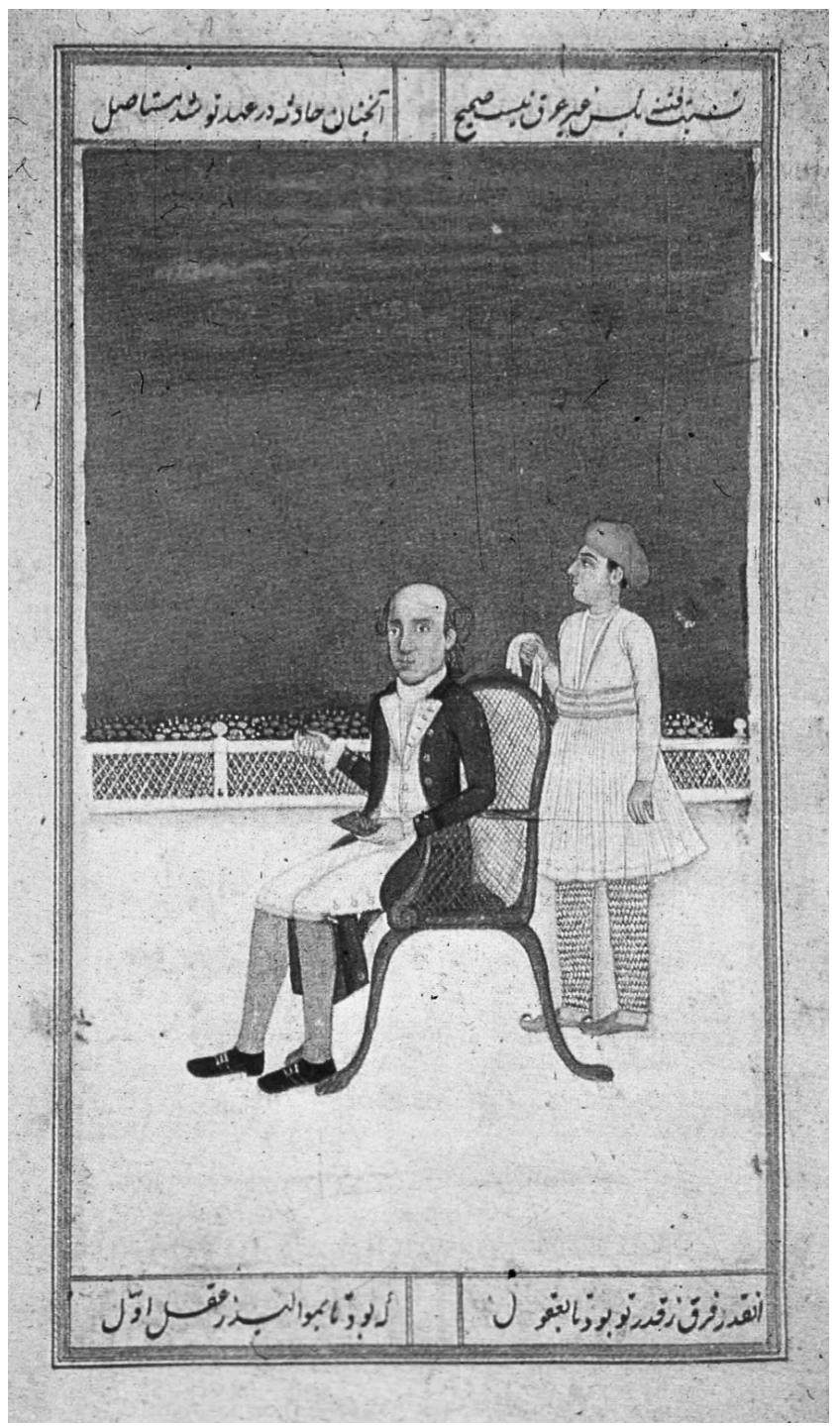

Figure 5. Anonymous Mughal artist, Warren Hastings, c.1784-1785, gouache, Add Or. 6633, Oriental and India Office Collections, by permission of the British Library, London.

a new agreement and horrified at the lavish entertainments Asaf had organized for him, which had the effect of increasing Awadh's debts to the Company. ${ }^{42}$ Yet, in the eyes of one of the court's poets, this had been a fabulous epoch characterized by lavish gifting: "At the time of his [Hastings'] departure, the exalt-

42 Hastings Papers BL: Add Ms. 29,121, 3 May 1784. 
ed nawab gave gifts to Hastings' men in such large numbers that no one could ever imagine. Every person of any note was given a horse, an elephant and a fine robe." ${ }^{33}$ Asaf wanted to project the image of an exalted emperor who gives to his subordinates and allies in dazzling, potlatch-like public displays of munificence, but this was at loggerheads with Hastings' parsimonious governance.

This was but one indigenous critique of British manners and style of governance: other instances even implicated Hastings' political physiognomy: “The English are a race of men who are keen sighted, full of policy and secrecy. But none more so than the governor whose breast is a casket full of inaccessible secrets and a repository of impenetrable views and projects.... Who can tell from his features, his air or his actions at any of the secrets locked up in that impenetrable breast? It is out of any man's power, it is utterly impossible." 44

Read in the context of Ghulam Hussain's wider criticism of the Company, Hastings' physiognomy acts as a metonymy for the impenetrable colonial archive and imperial rule through abstract 'principles' as opposed to indigenous face-to-face interaction. In Ghulam Hussain's view, the English avoid at all costs presenting their physical (as opposed to painted) selves to their Indian subjects: "They hate appearing in public audiences; and whenever they come to appear at all it is to betray extreme uneasiness, impatience and anger, on seeing themselves surrounded by crowds ... hence multitudes of people remain deprived of the sight of their rulers and never see anything of that benignity and that munificence which might be expected from people that now sit on the throne of kings and figure as representations of Emperors." 45

Throughout the Company's dominions, kingly displays of charisma were eroded, seemingly leaving little in their place. Hastings' attempts to introduce British portraits and portraitists at Lucknow and Hyderabad were only partially successful. Although Zoffany would spend three years at Lucknow, he had few commissions from the court and no British artist visited Hyderabad until the 1800s. Nizam Ali Khan accepted Hastings' likeness with at least outward pleasure and Asaf agreed to sit repeatedly for Zoffany, so that colonial art and artists could provoke 'events' - Anglicized rituals that demanded nawabi participation. Although both Hastings' and Johnson's missions ultimately failed, in other contexts art and politics were already being entangled in more ominous ways.

THE DEVASTATION OF THE GIFT: COLONIAL PAINTERS AT ARCOT AND LUCKNOW

Whilst Hastings tried to deploy the exchange of portraits at still-independent Hyderabad as a means for negotiating cultural difference, at courts already

\footnotetext{
43 Mir Muhammad Taqi 'Mir,' Zikr-i Mir, p. 124.

44 Ghulam Hussain Tabataba'i, Siyar al-muta akhkhirin, vol. 3, pp. 329-30.

45 Ibid., vol. 3, p. 597.
} 
coming under indirect Company control, colonial likenesses began to subvert indigenous gifting and patterns of artistic patronage. Hastings' peculiar mimicry of the Mughal gift grafted on the British custom of portrait-exchange had a cutting edge: it operated as de facto tribute from the indigenous rulers for which no return gift was made. At Lucknow and Arcot, Hastings and his successors dispatched British artists to take the likenesses of these nawabs, but did not reciprocate with their own portraits. Instead they annulled or at least mystified the notion of art as gift, anticipating that these princes would send their likenesses to the Governor-General and pay the British painter for this privilege. In effect, the portrait-gift became a species of tribute. Colonial portraits may not have been objects to be exchanged, but they did possess a type of mimetic inalienability that these rulers could use to their advantage. Although the idea of a beneficial material return was destroyed, as the Company tried to bleed these courts white, the reciprocation in the gift was not entirely obliterated.

The difference between British and Indian ideas of inalienability and obligation now structured the image-gift. During a diplomatic mission to Lucknow in 1797, Governor-General Sir John Shore described these conflicting interests to his wife:

This day I had a private audience with the nawab . . I have refused a fortune . . my answer ... was this; that a barleycorn from him was equal in my sight to a million rupees; but I could not but express my concern that he and his people were ignorant of our customs and my character to make such an offer ... I added that I had seen in his shusha khana [sic] ['mirror room'] —-some pictures of his ... of which I begged to have one as a memorial of our friendship ... I took one about fifteen inches square done by Zoffany, not set in diamonds, which is a strong resemblance to the nawab and for which to say truth, I would not give two pence. It pleased him. ${ }^{46}$

Shore claimed that a single grain outstrips a million rupees, that this singular token alone could embody the nawab's exalted presence-that it is gift enough. Yet his private correspondence deflates the 'inalienable' image-gift into little more than a banal souvenir. In cases such as this, what happens to the return demanded by gift? Whilst much gift literature argues that the donor acquires superiority over the receiver and in the process creates indebtedness, here the recipient solicited the gift through a covert exercise of his power over the giver, by forcing him to part with what Shore perceived to be an 'inalienable possession.' 47 Anticipating this colonial pressure to give, Asaf invited British officials to the anglicized spaces of his palace or presented his colonial-painted likenesses to colonial governors, hoping to deflect the scopic drive of the Company from the inner lives of his court and from his preferred definition of 'inalienable possessions'-Mughal and Persian art. During the same period Company officials voraciously 'collected' rare illuminated Mughal manuscripts,

46 V. Manners and G. Williamson, Life and Works of Johann Zoffany R. A., London: John Lane, 1920 , p. 20.

47 Mauss, The Gift, pp. 45-67. 
which on return to Britain they frequently claimed were presents, or which they gifted to George III as part of their desire for personal accolades. ${ }^{48}$ That Asaf's portrait was "not set in diamonds" indicates that soliciting diamond-studded portrait-gifts signified as a common practice. From a colonial perspective, to ask for a picture in a diamond frame (legal and reportable in colonial documents) contained a crucial subtext as the nawab himself wanted to use such pictures to foist a sense of personal obligation onto the recipient.

What happened to these colonial pictures once they left the confines of nawabi courts? Apart from gifting his portrait to George III, the nawab of Arcot, Muhammad Ali also sent his likenesses to the Governor of Madras, to the Company's Court of Directors, and to Hastings. Writing to thank him, Hastings bestowed the image an iconic importance: "For want of a better place to put it, it will hang in the Court House along with the portraits of the King and Queen of England. As this is the room where all public ceremonies are held, as well as the court of justice, the portrait will become the object of attention." 49 Hastings 'orientalizes' the Court House in Calcutta to provide an 'occidentalized' version of the Mughal 'hall of audience,' wanting to create an arena of political and civic importance that did not in reality exist. Since the court and the assembly room were on different floors, there could not possibly be a British equivalent of a nawab's palace.

These display strategies became entangled in the difficult negotiations between artists, nawabs, and governors. Towards the end of his stay at Arcot ( $f l$. 1774-1780), the Scottish portraitist George Willison complained to Hastings: "For a portrait of the nawab ... I have ever since been soliciting the payment of this picture that was sent you and having now the space of four years been assured with repeated promises of the nawab . . . but I find myself as distant from my reward as I was the first day and I am afraid it will be my hard fate to submit to the necessity of putting up with the loss . . . even after repeated intentions that I have given him of the necessity that he had put me under of applying to you and repeated requests on his part that I would not do so, as he would pay me himself. You will easily see how unwilling I was to trouble you with this demand." 50

The noted art historian Mildred Archer suggests that Muhammad Ali, for

\footnotetext{
48 For instance, in 1799 John Shore, again at Lucknow, was 'gifted' the famous Padshahnama manuscript, now in the royal collection, at Windsor Castle. Asaf ud-daula had died in 1797 and the politics of succession had been fiercely fought — the British pushing their candidate Saadat Ali Khan to accession. During this coup, the famous Padshahnama was 'gifted' along with five other Mughal manuscripts: "this is the most splendid Persian manuscript I ever saw . . which was shown to $m e$ at Lucknow and I was there informed that the deceased Nabob Asophuddoulah purchased it for 12000 Rs., or about $£ 1500 ”$ (my emphasis); M. C. Beach and E. Koch, King of the World: The Padshahnama Manuscript, London: Windsor Castle publications, 1997, p. 13.

49 Mildred Archer, India and British Portraiture, 1770-1825, London: Sotheby Parke Barnet, 1979 , p. 123.

50 George Willison to Hastings; Hastings Papers BL: Add Ms. 29,145, f. 203.
} 
'having the honor' of a British artist at his court, should have paid for the portrait and sent it as gift to Hastings in Calcutta. ${ }^{51}$ Yet in Britain portraits were rarely paid for by their sitters: rather the picture's recipient, eager to have the likeness of the person portrayed, paid the painter's fee.

The East India Company was demanding as much as half the annual revenue of kingdoms such as Awadh, and so it could well afford to pay for nawabs' portraits: its refusal underscores the ambivalence of the Company's foreign policy even in the petty domain of face painting. British portraitists Willison, Zoffany, and Ozias Humphry charged their Indian sitters as much as they could. Willison wanted "double at the durbar," whilst Humphry increased his prices by 100 percent, billing Asaf ud-daula one thousand pounds for a miniature. However nawabs spent lavish money on Mughal art and artists. Asaf accumulated a priceless collection of Mughal imagery from war-torn Delhi, purchased thousands of manuscripts such as the Padshahnama (King of the World chronicle) for twelve thousand rupees, and paid thirty thousand rupees for a single portrait of Jahangir. ${ }^{52}$ Nawabs rewarded their own painters with land grants (in part to encourage artists from Delhi to settle in the successor states), as well as with elephants, titles, and money in line with the treatment of army officers and poets. ${ }^{53}$ Their posts were often hereditary or at least long-term and, even if they sometimes went unpaid, their status differed radically from itinerant colonial painters who were recommended but not directly patronized by the Company.

Humphry, Willison, and Zoffany hoped to capitalize on their 'novelty' status and on their support from Company Residents. On arrival at Lucknow and Arcot they were presented to the nawabs by the Resident and then symbolically 'incorporated' in the court through their presentation of nazr in return for khil${ }^{3}$ at ${ }^{54}$ Yet their position, caught between the Company and court, remained precarious. Although Hastings maneuvered British artists across India, his successors Sir John Macpherson (1785-1786) and Lord Cornwallis (1786-1793) maintained a far more ambivalent attitude towards these portraitists. Given this lack of official interest, coupled with the reforms of the Parliamentary India Act of 1784 and economic recession, Calcutta's colonial portrait market had collapsed by 1786 . Desperate painters left in search of either exotic landscapes as the inspiration for print schemes, or for portrait commissions at Indian courts. This exodus of artists reached a crisis point at Lucknow in the later 1780s, where Johann Zoffany, Charles Smith, and Ozias Humphry all sought to make their fortunes. The Resident, Colonel Harper, complained to Macpherson that, "I know not what to do about Mr. Humphry and Mr. Smith the painters. If the nawab should sit to be painted, the Lord knows when they will reap the ad-

51 Archer, India and British Portraiture, p. 45.

52 Madhu Trivedi, The Cultural History of Awadh, Ph.D. thesis (unpublished), Aligarh Muslim University, 1977, p. 50.

53 Ibid., p. 226.

54 Ozias Humphry, “Lucknow Diary,” Eur Ms. Photo 43 (OIOC) 1786, f. 4. 
vantage of their labors. If I were to wish my greatest enemy the most perplexing situation, I should for the present make him Governor-General's agent at the courts of the Shahzada and the Vizier." 55

Too many painters now encroached on the domain of diplomacy, especially as Asaf wanted to banish Europeans from his kingdom: "It is particularly unlucky that Mr. Zophani is here too ... [yet he has] had very little reward for his labors as yet, if any, and I fear the present nawab is not of a disposition to be very liberal. Though he is taught to believe $\mathrm{Mr}$. $\mathrm{Z}$ a first rate artist, and is as much pleased with his pictures as he can be with any, yet I am persuaded that the nawab and his court prefer their own common country pictures to any Mr. $\mathrm{Z}$ can do." 56

Throughout his reign Asaf, like his predecessors, favored past and present Mughal art. In many of his indigenous portraits painted during his lifetime, the nawab is represented as slim and active-often hunting or else commemorating Muharram (figure 6) - images that deliberately distance themselves from what Britons perceived as his decadence captured by those full-face portraits by Kettle, Zoffany, Smith, and Humphry. ${ }^{57}$

In his introductory letter for Ozias Humphry, Macpherson expressed his hope that the nawab would prove a generous patron:

Mr. Zoffany and Mr. Smith are artists in different styles. I hope your Excellency will show them attention and favor. There is another style of painting, that of drawing perfect likenesses in small pictures, which is most agreeable, because the hand of friendship can always carry them as a remembrance. The most eminent gentleman in England in this line of painting is Mr. Humphry, whom I have deputed to the Presence to bring me pictures of Your Excellency, of the Shahzada, and of your son and of your ministers. He will show [not gift] your Excellency a picture of me, and it is a true resemblance.

Till I have the pleasure of a personal interview with your Excellency, make me happy by sending me your picture, and by your attention and favor to Mr. Humphry, who has drawn pictures of some kings of Europe and who has met with favor from the king of England. It is worthy of princes to favor men who are eminent in the fine arts. What can I say more? ${ }^{58}$

"Favor" signified a calculated colonial ambivalence; neither the Company nor the nawab agreed to these painters' exorbitant demands. Macpherson did not 'gift' Asaf his own likeness and Humphry would later force him into a lengthy litigation in Calcutta for not paying his fees. Humphry had initially sought payment from the nawab but on failing he changed his argument by stating that Macpherson had employed him first to paint his likeness and then to make portraits of the Lucknow court. Humphry tried to use the ambiguities of

55 Archer, India and British Portraiture, p. 192.

56 Ibid., p. 192 (my emphasis).

57 F. L. Smith, "Letter from Lucknow, 1795," Asiatic Annual Register, London, 1804, pp. 97101.

58 Archer, India and British Portraiture, pp. 190-91. 


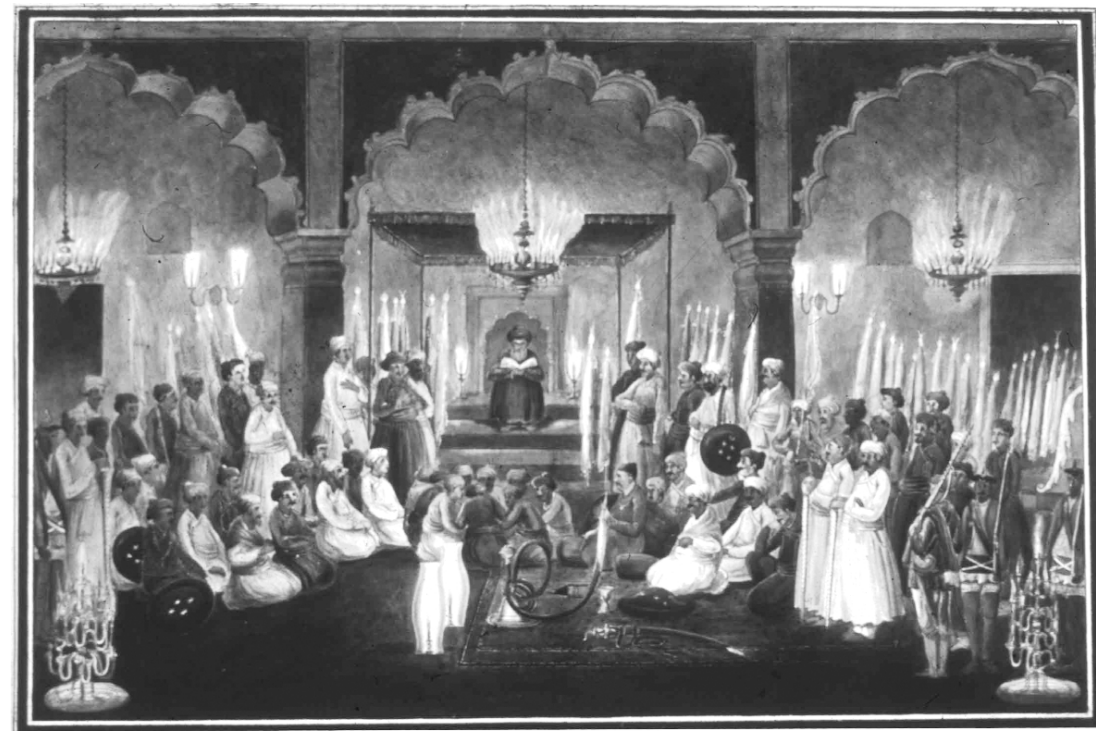

Figure 6. Anonymous Mughal artist at Lucknow, Nawab Asaf ud-daula in his Bara Imambara, c. 1795, gouache and watercolour, Add Or.2595, Oriental and India Office Collections, by permission of the British Library, London.c. 1795

colonial patronage to his own advantage, but ended up with nothing but a massive legal bill. ${ }^{59}$

Both the nawabs of Arcot and Awadh played British artists at their own game. By promising to meet their extravagant fees, but then delaying once the pictures were finished, Muhammad Ali and Asaf ud-daula used deferral as a strategy which had its own cost. Although these colonial artists left indigenous courts unpaid, they later tried to claim payment through Company intervention. Willison's bill at Arcot was eventually settled when incorporated with the nawab's debts that the Company recuperated through tankhwah-the assignment of revenue on a tract of land or its annexation to the Company. By the 1770s, tankhwahs had been used by both the Company and private traders in their attempts to recover loans from the nawab of the Carnatic, as well as providing a way of paying for mercenary troops stationed in foreign kingdoms. At Arcot, the internal order of revenue collection and the unity of the nawab's court had been destroyed by this system which created a network of Company inter-

59 Ibid., p. 194. See also Ozias Humphry, Lucknow Diary, p. 12. On arriving in India, Humphry was determined to make a fortune writing to his fiancée Mary Boydell, "I shall omit nothing that is in my favor to do to get money"; Humphry Papers HU/3/23, Royal Academy Library. For Humphry's preparation of his court case see HU/5 and HU/8; and BL: Add Ms. 13,532; Brief Account of the Case of Ozias Humphry; Humphry Papers BL: Add Ms. 22,951. 
ests across the Carnatic. ${ }^{60}$ Likewise in 1780s Awadh, the Resident at Lucknow initially promised Humphry a tankhwah to the value of $£ 4,830$ for the following year at 12 percent interest, although Humphry did not want to wait. At the same time, the Resident at Benares negotiated the oil portraitist Charles Smith's Lucknow fees through the promise of yet another tankhwah in exchange for the pay-off of debts owed to Europeans. ${ }^{61}$ Nine years after his return to London, the miniaturist John Smart who worked for ten years at Arcot, complained that his bill of $£ 1,600$ remained unpaid, and so he submitted several affidavits to the Company for principal and interest of $£ 2,5046$ s and $7 \mathrm{~d}$, "for which a tunka [sic] was granted on the Tinnevelly Provinces, but of which no part has been paid," whilst Zoffany applied to the Court of Directors to return to India in 1811 in search of his fees promised through another tankhwah. ${ }^{62}$ Although Smith and Willison were paid the money they 'owed,' the fate of Humphry, Smart, and Zoffany indicate that the Company used tankhwahs to appropriate their fees for itself. ${ }^{63}$ The demands of a few European artists may have been one among several motives for implementing land annexation, but their pleas were ultimately ignored by the Company's aggressive military and financial expansion into Indian kingdoms.

Despite these wrangles, the ambivalent agency of British portraiture did make a difference to Indian ideas of sovereignty. The very act of portrayal made new demands on painter and subject, as commissions were determined by complex encounters. The best-documented instance of these delicate negotiations is the encounter of Scottish portraitist James Wales' with the Pune court in the early 1790s. Unlike Arcot and Lucknow (increasingly under threat from Company), this Maratha court (under the young Peshwa, his minister Nana Phadnavis, and the formidable martial leader Shinde) was independent and powerful, being in control of much of western India as well as Delhi. In the eyes of the British Resident at Pune, Shinde had preconceived notions of how he wished to be represented: "Visited Mahajee Scindia and introduced him to Mr. Wales a portrait painter to whom he was good enough to sit near two hours. He expressed a desire that his picture may be drawn on horseback, observing that every man's character and way of life should be painted in his picture and that his whole life had been present in the field."64

${ }^{60}$ Gurney, Nawab of Arcot's Debts, pp. 112-56.

${ }^{61}$ Rosie Llewellyn-Jones, A Very Ingenious Man: Claude Martin in Early Colonial India, Delhi: Oxford University Press, 1992, p. 125.

62 Home Miscellaneous Series (OIOC) H/298, f. 1496; H/322, f. 469.

63 Both the Scottish artists Charles Smith and George Willison were well connected in London and Calcutta society - their relatives were politicians and Company Directors. This helped them to persuade high-ranking colonial officials to intervene on their behalf. Failing to settle issues of payment, Humphry, Smart, and Zoffany returned to London in the hope that they would be able to continue their struggle for money by petitioning the Directors or making contact with important Company officials such as Hastings.

${ }^{64}$ Charles Malet, Letter Book of Sir Charles Warre Malet, Eur Ms. F149/65 (OIOC) 1792, f. 43. 
Yet Wales' perception of Shinde emphasizes physical appearance above biography and action, observing that "although a chief of great powers [he is] nonetheless a person of mean appearance and rather low stature, fat and lame of one leg." ${ }^{\circ 5}$ The court of the Peshwa wished to be represented within a specific iconography of finest robes and jewels and to meet their demands, Wales was instructed to work "in an uncommon state ... as the natives are very fond of high finished pictures." ${ }^{66} \mathrm{He}$ also complained that "as people of distinction in India are fond of fine or rather rich dresses with watches and snuff boxes, rings etc. introduced, it is no easy matter for an artist to please them without sacrificing the best principles of his art." ${ }^{67}$ Wales' pictures of the Peshwa and his ministers were hung in a specially designed bungalow where they would later become 'iconic' by being adapted by local artists, Chinese painters, and lithographers. ${ }^{68}$

The introduction of large-scale European canvases into Indian kingdoms redrew the boundaries between space and subject. Whilst Mughal illuminated chronicles had included representations of the emperors' loyal allies gathered in audience halls, such imagery was not exposed to public view. Instead, the ruler presented his physical presence to his people, framed by attendants and the jharoka-i darshan (the ceremonial window in the outer face of the palace that allowed crowds to experience the physical presence of their ruler). In contrast, a colonial canvas of the nawab standing alone before the viewer fulllength and full-face was now integrated within the spatial actuality of the ruler's palace. Here the portrait was made to give darshan, which has a central role in the Indian scopic regime. ${ }^{69}$ Darshan's mode of interaction mobilizes vision as part of a unified human sensorium and visual interaction can be physically transformative. In darshan seeing is conceived as an outward reaching process, as extrusive, a medium through which the seer and seen come into contact. Appropriated by both Indian and British publics, colonial portraits acted as doubled presences. They were infused with the human and the divine as the iconic body signaled in and of the image. European realism becomes an attribute of Indian sovereignty, as the agency of both the Company and the painter is erased by the all-seeing eye of Indian kingship.

Wales' portrait of Shinde was displayed posthumously in the leader's mausoleum, giving darshan to much wider audiences than the visitors to Indian courts. Here his painted likeness was located alongside his body, creating a presence that entangled the image with the relic: "It is a small pagoda where in

65 James Wales' Diary, Sitters Book and Accounts 1792-95, vol. 1, ff. 11-12 (Yale Center for British Art, New Haven: Ms. Fo. 21.7.1976).

66 Ibid., f. 31.

67 Ibid., f. 12.

68 Christopher Pinney, 'Photos of the Gods': The Printed Image and Political Struggle in India, London: Reaktion, 2004, pp. 45-59.

${ }^{69}$ Diana Eck, Darshan: Seeing the Divine Image in India, New York: Columbia University Press, 1996. 
the usual place of the principal deity is a picture of Scindia [sic] by Zoffany, very like that in Government House, Bombay. Before the picture, a light is kept constantly burning and offerings daily made by an old servant of the maharajah ... this portrait by Zoffany is probably the only work in European art which is now the object of adoration; it has obtained one honor refused the Transfiguration itself." 70

Thus, Indian kingship managed to maintain a distinction despite the Company's onslaughts. The changes in art patronage instigated by colonialism (whether portraits or collecting) had the unexpected effect of creating a highly visible public forum over which the Company had no direct control and of which it had limited comprehension. In spite of their negative comments about Indian uses of colonial artifacts, Company officials were ultimately confounded by this nawabi enchantment with British art.

\section{FROM GIFT TO COLLECTING IN NAWABI INDIA}

Whilst portraits of the nawabs were incorporated into the indigenous kingly repertoire, how did other British pictures (especially prints) signify in kingly contexts? Central to princely self-fashioning was the Mughal idea of the Padshah - 'the king of the world,' which implied a certain cosmopolitanism vis-àvis rarities and artifacts, and the Mughal rulers were well-known for their extensive collections drawn from Europe, China, Persia, the Ottoman Empire, and elsewhere. The successor states inherited this 'cosmopolitanism' as part of their legitimation exercises. Unlike oil portraits, prints could be pasted in albums alongside Mughal miniatures and they provided an ethnographic view of England and other parts of the globe. But by the 1780s, the nature of rarity had changed due to intrusive colonial trade-Western goods which even fifty years previously had been considered rare and exotic were not only found in abundance in transregional markets but now also resonated with an unwanted colonial presence.

Most descriptions of nawabi displays and collections were written by colonial governors, Company officers and occasionally by British painters, who framed their responses in terms from a discourse of despotism and decadence. I wish to read this archive critically so as to reveal not just the limits of colonial understanding, but more importantly, to bring out the agency of British art in the construction of Indian sovereignty. There are two intersecting agendas to be explored: the extraction of kingly power from European things and the deconstruction of colonial tropes for denigrating nawabi comportment. Company officials necessarily imagined the indigenous appreciation of British art to

70 The Scottish officer James Macintosh on a visit to Pune in 1808, cited in B. Paravasnis, Poona in Bygone Days, Bombay, 1921, pp. 66-67 (my emphasis). Whilst Hastings wrote to Muhammad Ali that his portrait was now an "object of attention" in Calcutta's colonial community, in Indian society Macintosh suggests that Shinde's portrait has become an "object for adoration," that transgresses the role for images in Catholicism and which blurs the boundaries between idol and fetish. 
exist at an inferior level to their own perception, and thereby questioned the endurance of those aesthetic values encoded in these artifacts as these crossed the border of cultural difference. Nawabi exhibition spaces became embattled grounds for conflicting ontologies of art, display, and possession.

By the 1770s, markets for imported pictures, especially prints, were wellentrenched in Calcutta, Bombay and Madras - prints proving to be the most enduring item of art consumption of the British diaspora. ${ }^{71}$ Relatively cheap (in comparison with Mughal manuscripts and colonial oil portraits) and arriving framed and glazed, these patriotic, disposable, and portable things could weather economic recession, the heat, and the humidity. The biggest collectors of English prints were located in and around Indian courts such as Seringapatam, Arcot, and Lucknow. At Lucknow, the French colonel Claude Martin trafficked in European art by creating a network of auctioneers and painters that extended as far as Paris and London. He not only constructed a massive personal collection of pictures totaling several thousand Mughal, Chinese, and European images (which he displayed in his two Lucknow houses), but he also sold prints to Asaf ud-daula by lending him money at 3 percent interest per annum. ${ }^{72}$ Unlike the rented colonial apartments in Calcutta, where usually only four or five prints were displayed 'tastefully' in the hall, Asaf's enormous collection of prints both awed and repulsed his British visitors.

Such colonial responses were undergirded by ideas of European collecting practices. By the 1780s, the idea of 'the collection' in Britain increasingly emphasized the cult of the collector's personality: collectibles should manifest his individual sense of engagement with the world and his ability to order it as a unified, highly personal yet disinterested schema: "there is something of the harem about [Western] collecting, for the whole attraction may be summed up as that of an intimate series ... combined with a serial intimacy." ${ }^{73}$ For Britons, prints signified differently at Indian courts. Framed and glazed, they became less individual works than reflecting surfaces to be either superimposed on or replace elaborate marble and mica (metal/mirror) decoration.

Colonial writers grappled with ways to comprehend such complex spaces. They described the display of European art in the glass house/treasure-house of Asaf ud-daula's Asafi Kothi palace as cluttered and incoherent: oil paintings and prints clamor for attention with French mirrors, chandeliers, hand organs, and mechanical curiosities. ${ }^{74}$ For instance, Boydell, the nephew of London's leading print seller, described Asaf's collection to Ozias Humphry: "The cabi-

\footnotetext{
71 Natasha Eaton, "Excess in the City? The Consumption of Prints in Colonial Calcutta," c. 1780-95, Journal of Material Culture 8, 1 (2003):45-74.

72 Rosie Llewellyn-Jones, Engaging Scoundrels: True Tales of Old Lucknow, Delhi: Oxford University Press, 2000, p. 30.

73 Jean Baudrillard, The System of Objects, J. Benedict, trans., London: Verso, 1996, p. 88.

${ }_{74}$ Banmali Tandon, The Architecture of Lucknow and Its Dependencies, 1722-1856, Delhi: Vikas, 2001, p. 88.
} 
net at the palace contains a great many costly articles but did you ever see such a heterogeneous arrangement? The first impression was so unfavorable that I could not even look at a few pieces with any pleasure ... In short my plan was to a merchant's warehouse or [to] enter an auction room and there it stayed several hours after I quitted the place." ${ }^{\text {75 }}$

Boydell's expression-"merchant's warehouse or an auction room"-alluded to the public sites where thousands of newly imported or else second-hand prints were displayed in Calcutta. For a colonial society conspicuously lacking a public art forum, salerooms provided useful surrogates. Yet once pictures had passed into the realm of private possession, the comparison with a grand colonial space filled with other imported commodities problematizes this commercial analogy. Sir John Shore described the Lucknow ai" nakhana as "literally a glass house but a complete Europe shop," since conflicting spatial identities coexisted uneasily. ${ }^{76}$ The commercial analogy refers to the colonial warehousespectacle which is defined by unsold commodities and is not identified as a collection, yet the $a i$ " nakhana's existence as a "glass house" also evokes the Mughal display of rare glassware from Persia, Europe, and China in apartments known as chini khana (china rooms). That Shore, an experienced Orientalistadministrator, cannot reconcile these different spaces admits the failure of colonial scopic drive and the inability of the metropolitan imagination to understand these collections as nawabi heterotopias, as counter-sites, as a kind of effectively enacted utopia - the materialization of a certain cosmopolitical aspiration to the Padshah. As Bhabha put it cogently, "it is not that the voice of authority is at a loss for words. It is rather that colonial discourse has reached that point when, faced with the hybridity of its objects, the presence of its power is revealed as something other than what its rules of recognition assert."77

This fundamental ambivalence was inscribed in the very location of imported art objects in nawabi collections: these objects had to become porous enough to absorb the 'Padshah' aura. Colonial accounts of the collection of Asaf observed that his own portraits play a vital role in these displays. It is this semidivine agency that provides the organizing template for nawabi collecting. Instead of the Mughal Emperor represented by his painters standing on top of a globe, here the nawab uses his likenesses to convey his sovereignty-in-theworld: "He had an immense room filled with all sorts of curiosities forming a ridiculous museum as perhaps could not be met with elsewhere in the world. Toys of all descriptions-Chinese, Dutch, English, huddling together with some of the finest pieces of mechanism ever made by man. Some of the finest paintings by the first masters [were] hanging promiscuously with China daubs.

75 S. Boydell to Ozias Humphry, Humphry Papers Royal Academy, HU/3/45, f. 98.

${ }^{76}$ Lord Teignmouth, Memoirs and Correspondence of Lord Teignmouth, London: Hatchard, 1843, pp. 410-11.

77 Bhabha, Location of Culture, p. 112. 
His own picture painted by natives, by Zoffany and others might be seen in different dresses at every few paces."78

In spite of Asaf's omnipresence, Daniel Johnson returns to the usual colonial stereotypes of an incoherent display by paraphrasing earlier accounts of the Lucknow court, most importantly Lewis Ferdinand Smith's article in the Asiatic Annual Register. Smith had written that "contiguous to the palace there is a museum called the Inah Konnah [ai nakhana] . . . worthy of observation . . . not more so for its elegant pieces of mechanism, paintings and other articles by celebrated artists, than for its ridiculous assemblage of finery and trumpery jumbled together."79 For Smith, Asaf's collection is a "museum" that "is curious, rich and ridiculously displayed; you see a wooden cuckoo clock which perhaps cost a crown alongside a rich superb clock which perhaps cost the price of a diadem; an elegant landscape of Lorraine beside a deal board painting of ducks and drakes." ${ }^{80}$ He tried to explain the royal collection through Asaf's personality, extending European ideas of the collector to other contexts: "Asaf uddaula is absurdly extravagant and ridiculously curious, he has no taste and less judgment ... but he is extremely solicitous to possess all that is elegant and rare; he has every instrument and every machine, of every art and science; but he knows none ... [he is] a curious compound of extravagance, avarice, candor, cunning, levity, cruelty, childishness, affability, brutish sensuality, good humor, vanity and imbecility." 81 The heterogeneity of Asaf's collection is stressed as Other, opposed to a projected coherence of the European self.

The taxonomy most frequently applied to these different collecting practices was that of the 'curious,' as English prints become curios due to their radical decontextualisation. A rare 'tourist' (as opposed to colonial trader/official) to Lucknow, Lord Annesley, perceived Asaf's art display as the place "where are deposited a part of the whimsical curiosities purchased by the late Asaf uddaula . . . consisting of several thousand English prints framed and glazed" and the artist William Daniell likewise categorized the ai nakhana as the repository for the "nawab's curiosities." 82 By the late eighteenth century, the curious was increasingly articulated as infantile, irrational, and effeminate, "licensed in the sense of licentiousness rather than authorization" conveying an "over determination of intellect by corporeality" defined by the sensual verbs "aroused" or "gratified." 83 Edmund Burke condemned curiosity as "the first and simplest emotion which we discover in the mind" associated closely with novelty in that it "has an appetite which is very sharp but very easily satisfied" so that in ef-

78 Daniel Johnson, Sketches of Field Sports in India, London: R. Jennings, 1822, p. 188 (my emphasis).

79 Asiatic Annual Register, London, 1808, p. 100 (my emphasis).

80 Smith, Letter from Lucknow, p. 98.

81 Ibid., p. 101.

82 Lord Annesley, Travels, London, 1809, p. 135; William Daniell, Diary, 1789, vol. 3, p. 12.

83 Nicholas Thomas, In Oceania: Visions, Artifacts, Histories, Durham: Duke University Press, 1997, p. 189. 
fect it cannot properly be termed as an aesthetic way of seeing except in the most primitive or infantile sense. ${ }^{84}$

If 'excess' was the leitmotif for colonial denigration of Asaf's collection, a rhetoric of impoverishment played a similar role in the case of the Bengali court of Murshidabad. Annexed in the 1760s, Murshidabad lost all power to the Company. The nawab's palace was described by Britons as despicably shabby: "Nothing but a square plait of . . . poppies peeping through the uncut grass" and the nawab's apartment as "decorated with English furniture-two ill-painted pictures of two English ladies were hung at each end of the hall." 85 A later account represented it as "neglected beyond conception. Weeds and rubbish filled the corners . . . the walls whitewashed, arches ornamented with painted wood colored and carved with equal coarseness. A few English fox hunting prints of the secondary quality decorated one side" — hardly the appropriate imagery for a prince. ${ }^{86}$ Unlike Lucknow, Murshidabad had no European-style palace, and its open, multi-pillared, pre-colonial structure was not designed for the display of vast quantities of British art. The palace was the only space where the nawab retained direct jurisdiction, so that in colonial rhetoric its neglect warns of bad native governance rather than the reality of ruthless household cuts imposed by the Company.

Paradoxically, the same type of imagery was being consumed by the British in Calcutta. The British thought of their imagery as a civilizing agent that possessed the apparent ability to act as a litmus test so as to gauge the state of the society in which it found itself. According to European standards of taste, "a work of art has meaning and interest only for someone who possesses the cultural competence, that is the code, into which it is encoded," and that a "beholder who lacks the specific code feels lost in a chaos of . . colors and lines," is arrested at the primary stratum of meaning at a sensual level. ${ }^{87}$ For British critics, Asaf's connoisseurship, or the lack of it, defined by his enormous expenditure on British art, is indiscriminate, but at Murshidabad, with only limited funds to spend on pictures, 'excess' is stripped away to reveal that beneath eclecticism lay a debased taste.

Yet these regional rulers did use British art in ways that suited their purposes: there remained an irreducible moment of agentive appropriation. Asaf filled his

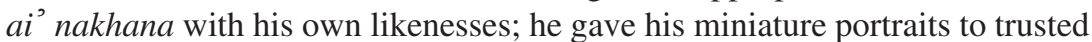
allies, he rebuilt Lucknow as a magnificent city and he asserted a strong Shi' ite identity - all of which emphasized his sovereign cosmopolitanism at a time when the administration of his realm was being gradually undermined by the

\footnotetext{
${ }^{84}$ Edmund Burke cited in Thomas, Entangled Objects, p. 116.

85 Anonymous, "Account of Murshidabad," Calcutta Chronicle 1 May 1788, pp. 1-2.

86 The Marchioness of Bute, The Private Journal of the Marques of Hastings, London: Saunders and Otley, 1858, vol. 1, pp. 81-82.

87 Pierre Bourdieu, Distinction: A Social Critique of the Judgment of Taste, R. Nice, trans., London: Routledge, 1999, p. 2.
} 
British. But at base Asaf retained an ambivalent approach toward British art. No British painter was satisfied with his treatment in Awadh, as the nawab irrevocably favored his own court art to anything British. ${ }^{88}$ However, inviting

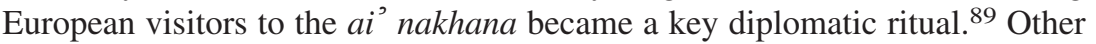
courtly apartments (from the durbar hall to the zenana) remained deliberately divorced from Europeanization. If colonial objects were sometimes present, they usually signified as portable splendor: "chairs and sofas were produced when English visitors were expected," only to be removed later so as to recover the space for nawabi habitation. ${ }^{90}$

The display of British art acted as a nawabi source of strength. Money lavished on European goods maneuvered revenue away from Company surveillance or control. Instead of paying off British debts, Asaf and his successor Sa adat Ali Khan (1798-1814) built up commission networks with private traders whose relations with the Company were equivocal. ${ }^{91}$ Images participated within the game of bluff and counter-bluff as nawabs sought to exclude the British from surveillance, access, or control of Awadhi resources. Conspicuous consumption was itself turned into an obstinate resistance. ${ }^{92}$

\section{CONCLUSION: MIMESIS AS ALTERITY}

The unpredictable effect of introducing colonial art to Indian courts urges revision both of the view that the Company had minimal impact, and its inverse that colonialism was productive only of devastation on a large scale. In terms of material culture, the colonial encounter generated deep cultural meanings and productive ambivalences. The Regulating Act stipulated that some objects made implacable demands — such as land and money — which had to be eliminated from Anglo-Indian prestation. In contrast, Britons perceived portraits and prints to be symbolic gifts that seemingly transcended economic corruption, but which in fact generated equally potent and problematic conflicts. Whilst British journals and books emphasized the triumph of the Company's art trade, the private papers of colonial officers, governors, and artists expose nawabi hostility, indifference, or at best ambivalence toward European imagery.

Under Company pressure, nawabs may have given their British portraits as tribute, but this must be contextualized in their wider practices of artistic patronage whose mainstay was indigenous art, continuing well into the nineteenth century. Although the Company prohibited Awadh from interacting with other states, the indigenous elite sought to reclaim their Shi' ite 'cosmopolitanism' by

\footnotetext{
88 No portrait painter was swiftly paid and Ozias Humphry records that Asaf sat three times "without any apparent impatience," which suggests that Humphry expected the nawab to have an aversion to British artists; Humphry, Diary, f. 6.

89 Asiatic Annual Register, p. 106.

90 William Knighton, Private Life of an Eastern King, London: Longman, Roberts and Green, 1921, pp. 241-42.

91 Llewellyn-Jones, A Very Ingenious Man, p. 126.

92 Barnett, North India Between Empires, p. 101.
} 
transforming Lucknow into an important religious center. The Shi ite rulers of Murshidabad and Hyderabad also reformulated the strategy of displaying their kingly charisma, and emphasized the importance of a public realm where the British had little control. These, then, were no mere 'theatre states' - these rulers fashioned a critical multiculturalism that negotiated diverse political and artistic influences. Their 'borrowings' of European art never copied colonial practices but rather marked out their differences.

Instead of anthropologizing these other meanings of 'art' as mere decontextualization, I want to strive for a 'heteroglot' art history - art as a site for dialogical engagement with the strange and the aporiatic: the twilight world of the nawabs. To that end, Taussig's notion of "mimetic excess" helps us to understand how stable identity-formations auto-destruct to produce excesses of meaning unrecoverable through the problematic of 'recognition' and the kind of totalizing dialectic it entails. As the West gets everywhere, through goods and images, its own identity against which the mimetic alters can be constructed notoriously eludes fixing. Hastings' mimicry of metropolitan portrait-exchange is further mimicked in its colonial incarnation as these images become emblematic, at least partially, of Mughal tribute-in-gift. Western prints hang upside-down in nawabi displays, becoming auratic cult-objects, and colonial portraits of nawabs dither in their radical uncertainty between conflicting visual ideologies of presence. There is much more to these colonial excesses than just mimicry. Colonial excesses and ambivalences are productive in the sense that these are mimesis of mimesis, mimesis made aware of itself-self-reflexive mimesis. When mimesis itself is mimicked, as in nawabi displays of British art, it is not quite difference and not quite repetition. Paradoxically, this density of representation-representation of representation and representation within representation-problematizes representation itself. It demands and yet disrupts "any possibility of mastering the circulation of mimesis in alterity." 93

93 Taussig, Mimesis and Alterity, p. 36. 